\title{
An Evaluation into the Physical Activities of Housewives at Different Educational Level (Case of Amasya)
}

\author{
İskender Güler (Corresponding author) \\ Department of Physical Education and Sports, Faculty of Education \\ Amasya University, Amasya, Turkey \\ E-mail: iskender.guler@amasya.edu.tr
}

Received: September 18, 2021

Accepted: October 18, 2021

Published: November 11, 2021

doi:10.5296/jei.v7i2.19020

URL: https://doi.org/10.5296/jei.v7i2.19020

\begin{abstract}
The main premise of this paper is to examine the physical activities of housewives at different educational level in the center of Amasya Province. A total of 340 volunter housewives from different socioeconomic status were randomly recruited. We collected the data through the Physical Activity Assessment Questionnaire (PAAQ). We employed descriptive statistics, including mean, standart deviation, minimum and maximum values, frequencies and percentages regarding physical qualities and activities. We performed the a Pearson Correlation Analysis to evaluate the relationships between physical qualities and activities. Based on the statistics, the distribution of the weekly activities of the participants are as follows: $44.4 \%$ of housewives walking, $8.8 \%$ jogging, $80.0 \%$ housework, $51.8 \%$ shopping, $52.4 \%$ climbing up stairs (40 steps or less). $2.4 \%$ doing step-aerobic activities, $24.1 \%$ babysitting, $2.6 \%$ using a computer and $52.2 \%$ watching television. Further, we found that as the education level of housewives increased, their use of cars and reaching a destination on foot increased ( $\mathrm{p}<0.05, \mathrm{p}<0.01)$; that BMI levels decreased significantly ( $\mathrm{p}$ $<0.01$ ) with the increase in education levels, working days and on foot transportation, and BMI levels increased $(\mathrm{p}<0.01)$ with the increase in passive recovery times. In conclusion, it can be suggested that housewives in Amasya have some levels of physical activities to some extent, but these activities are mostly walking, shopping, babysitting and doing households.
\end{abstract}

Keywords: Physical activity, Housewives, Body mass index 


\section{Introduction}

Physical activity is defined as any bodily movement that results in energy expenditure. Further, physical activity is considered as physical activities performed with energy consumption by using muscles and joints in daily life, increasing heart and respiratory rate and resulting in different fatigue. Daily activities such as shopping, cleaning, using stairs, walking, various sports branches that include all or some of the basic body movements such as head and body movements, running, swimming, cycling, exercise and games can be considered as physical activities. Therefore, physical activity does not necessarily have a special time and a specific place, and it is an indispensable part of life by taking place in every spheres of life (Baltac1, 2012; Ehrman et al., 2005).

The sedentary lifestyle, which is common today, is seen as an important public health problem due to its negative effects on health. Physical activities reduce the risk of many chronic diseases and early mortality by supporting physiological, metabolic and psychological parameters and help maintain bone, muscle and joint health (Heyward, 2006). Many research results (e.g., ACSM, 2009; Baltac1, 2012; Ehrman et al., 2005; Glassberg \& Balady, 1999; Heyward, 2006; Karaca et al., 2000) show that physical activity habits contribute significantly to the preservation of health and quality of life. However, rapidly developing technology causes a decrease in the level of physical activity both in daily work and in the workplace (Karaca et al., 2000). The beneficial effects of regular physical activity on health are related to the duration and severity of exercise, and it is stated that regular exercise reduces cardiac events (such as infarction, hypertension), type 2 diabetes, colon and breast cancer, obesity, depression and anxiety, gallbladder diseases and osteoporotic fractures (ACSM, 2009).

Physical activity gains more and more value day by day in terms of maintaining a healthy life. From this point of view, the relationship between health and physical activity is felt more and more every day. The protection and improvement of physical health seems possible with a balanced diet and increasing the level of physical activity. Sedentary life is an important risk factor for systemic diseases such as obesity, blood lipid imbalance, atherosclerosis, hypertension, coronary heart disease, stroke and osteoporosis. In Turkish society, women have more sedentary lifestyles, that is, far from physical activities, and their health is significantly adversely affected by this sedentary life. In line with the traditional view that coronary artery disease primarily affects men, it seems to affect women to the same extent (Erkan, 2000; Glassberg \& Balady, 1999; Kalyon, 1995).

Given that housewives tend to have a sedentary lifestyle and therefore stay away from physical activities, the purpose of this research was to examine the physical activities of housewives in the center of Amasya Province.

\section{Method}

\subsection{Participants}

We recruited a total of 340 healthy volunteer housewives, $85.0 \%$ of whom were married and $14.7 \%$ of them were single, living in the city center of Amasya, with a mean age of 


\section{Macrothink}

$36.72 \pm 11.01$ years.

\subsection{Data Collection}

We collected the data through the Physical Activity Assessment Questionnaire (PAAQ), developed by Karaca, Ergen, and Koruç (2000). The official permission was taken by the governorship of Amasya. We randomly selected the houses to do survey.

\subsection{Data Analysis}

We employed descriptive statistics, including mean, standart deviation, minimum and maximum values, frequencies and percentages regarding physical qualities and activities. We performed the a Pearson Correlation Analysis to evaluate the relationships between physical qualities and activities. The formula we employed for BMI levels of the participants was BMI $=\mathrm{kg} / \mathrm{m}^{2}$.

\section{Findings}

Table 1. Physical qualities of women

\begin{tabular}{|l|l|l|l|l|}
\hline Varaiables & $\mathbf{n}$ & $\mathbf{x} \pm$ Sd & Minimum & Maximum \\
\hline Age (years) & 340 & $36.72 \pm 11.01$ & 15.00 & 75.00 \\
\hline Height $(\mathrm{m})$ & 340 & $1.64 \pm 0.07$ & 1.47 & 1.80 \\
\hline Weight $(\mathrm{kg})$ & 340 & $58.86 \pm 10.92$ & 40.00 & 91.00 \\
\hline BMI $\left(\mathrm{kg} / \mathrm{m}^{2}\right)$ & 340 & $22.00 \pm 4.22$ & 13.36 & 41.54 \\
\hline
\end{tabular}

The mean age of housewives was $36.72 \pm 11.1$, the mean height was $1.64 \pm 0.07$, the mean weight was $58.86 \pm 10.92$, and the mean BMI was $22.00 \pm 4.22$ (Table 1).

Table 2. Educational background of the participants

\begin{tabular}{|l|l|l|}
\hline Variables & f & \% \\
\hline Primary & 86 & 25.3 \\
\hline Secondary & 54 & 15.9 \\
\hline High school & 117 & 34.4 \\
\hline University & 69 & 20.3 \\
\hline Missing information & 14 & 4.1 \\
\hline Total & 340 & 100.0 \\
\hline
\end{tabular}




\section{Macrothink}

As shown in Table 2, the majority of women are primary and secondary school graduates. It is seen that $41.2 \%$ of the women are primary and secondary school graduates, while $34.4 \%$ of them are high school graduates. The rate of graduation from university is $20.3 \%$.

Table 3. The number of the children

\begin{tabular}{|l|l|l|}
\hline Varaiables & $\mathbf{f}$ & $\mathbf{\%}$ \\
\hline $1-2$ & 147 & 43.3 \\
\hline $3-5$ & 95 & 27.9 \\
\hline $6-9$ & 4 & 1.2 \\
\hline Missing information & 94 & 27.6 \\
\hline Total & 340 & 100.0 \\
\hline
\end{tabular}

The findings have revealed that $43.3 \%$ of housewives have $1-2$ children, $27.9 \%$ have $3-5$ children and $1.2 \%$ have $6-9$ children (Table 3 ).

Table 4. Weekly working status of the participants

\begin{tabular}{|l|l|l|}
\hline \multirow{2}{*}{ Variables } & \multicolumn{2}{|c|}{ Weekly Working Days } \\
\cline { 2 - 3 } & f & $\%$ \\
\hline $2-3$ days & 16 & 4.7 \\
\hline $4-5$ days & 64 & 18.8 \\
\hline 6-7 days & 52 & 15.3 \\
\hline Missing information & 208 & 61.2 \\
\hline Total & 340 & 100.0 \\
\hline
\end{tabular}

As shown in Table 4, 23.5\% of housewives work 2-5 days a week and 15.3\% work 6-7 days a week. 
Table 5. Daily working status of the participants

\begin{tabular}{|l|l|l|}
\hline \multirow{2}{*}{ Variables } & \multicolumn{2}{|c|}{ Daily Working Hours } \\
\cline { 2 - 3 } & f & \% \\
\hline $1-8$ hours & 84 & 24.7 \\
\hline $9-12$ hours & 37 & 10.9 \\
\hline $13+$ hours & 3 & 0.9 \\
\hline Missing information & 216 & 63.5 \\
\hline Total & 340 & 100.0 \\
\hline
\end{tabular}

The findings show that $24.7 \%$ of the women work $1-8$ hours a day, and $11.8 \%$ of them work 9 hours or more (Table 3 ).

Table 6 . The pyhsical activity status of the participants

\begin{tabular}{|c|c|c|c|c|c|c|c|c|c|c|}
\hline \multirow[t]{2}{*}{ Activity } & \multicolumn{2}{|c|}{$\begin{array}{l}\text { Weekdays } \\
\text { (Between 20-60 } \\
\text { and } 150 \text { minutes) }\end{array}$} & \multicolumn{2}{|c|}{$\begin{array}{l}\text { Weekdays } \\
\text { (Between } 1 \\
\text { and } 7 \text { days) }\end{array}$} & \multicolumn{2}{|c|}{$\begin{array}{c}\text { Weekend } \\
\text { (Between 20-60 } \\
\text { and } 150 \text { minutes) }\end{array}$} & \multicolumn{2}{|c|}{$\begin{array}{l}\text { Weekend } \\
\text { (1-2 days) }\end{array}$} & \multicolumn{2}{|c|}{$\begin{array}{c}\text { Months } \\
\text { (Between 3-6 and 24) }\end{array}$} \\
\hline & $\mathbf{n}$ & $\%$ & $\mathbf{n}$ & $\%$ & $\mathbf{n}$ & $\%$ & $\mathbf{n}$ & $\%$ & $\mathbf{n}$ & $\%$ \\
\hline Walking & 148 & 43.5 & 151 & 44.4 & - & - & - & - & 123 & 36.2 \\
\hline On foot & 215 & 63.2 & 218 & 64.1 & - & - & - & - & 126 & 37.1 \\
\hline By car & 79 & 23.2 & 86 & 25.3 & - & - & - & - & 126 & 37.1 \\
\hline Jogging & 28 & 8.2 & 30 & 8.8 & - & - & - & - & 19 & 5.6 \\
\hline Doing step and aerobic & 8 & 2.4 & 8 & 2.4 & - & - & - & - & 7 & 2.1 \\
\hline Using a computer & 7 & 2.1 & 9 & 2.6 & - & - & - & - & 7 & 2.1 \\
\hline Cooking & 277 & 81.5 & 302 & 88.8 & 208 & 61.2 & 212 & 62.3 & - & - \\
\hline Cleaning & 283 & 83.3 & 298 & 87.6 & 239 & 70.3 & 242 & 71.2 & - & - \\
\hline Washing-up & 266 & 78.2 & 277 & 81.5 & 194 & 57.1 & 201 & 59.1 & - & - \\
\hline Doing the laundry & 235 & 69.1 & 254 & 74.7 & 130 & 38.2 & 137 & 40.3 & - & - \\
\hline Ironing & 176 & 51.7 & 191 & 56.2 & 138 & 40.6 & 149 & 43.8 & - & - \\
\hline Shopping & 128 & 37.6 & 176 & 51.8 & 107 & 31.5 & 116 & 34.1 & - & - \\
\hline Babysitting & 40 & 11.7 & 82 & 24.1 & 30 & 8.7 & 53 & 15.6 & - & - \\
\hline Watching TV & 149 & 43.9 & 178 & 52.4 & 126 & 33.2 & 138 & 40.6 & - & - \\
\hline Cllimbing up stairs (f/\%) & $1-40$ & $223 / \% 65.6$ & $21-4$ & irs $14 / 4.1$ & $41-1$ & airs $3 / 0.9$ & - & - & - & - \\
\hline
\end{tabular}


When the daily physical activities of women are examined, it is seen that $44.4 \%$ have a walk every week, 43.5\% have walks lasting for between 20-150 minutes, $64.1 \%$ reach their destinations on foot, and $63.2 \%$ have between 20-150 minutes walks. In addition, $25.3 \%$ of them reach their destinations by car every week and $23.2 \%$ of them use a car between $20-150$ minutes. Again, about $80.0 \%$ of women do housework every week, $75.0 \%$ do housework between 20-150 minutes, $51.8 \%$ do shopping every week and $37.6 \%$ do $20-150$ minutes. $8.8 \%$ run every week, $8.2 \%$ run between 20-150 minutes, $2.4 \%$ do step-aerobics every week, and $2.4 \%$ do step-aerobics $20-150$ minutes. Further, $2.6 \%$ use a computer every week, $2.1 \%$ use a computer between $20-150$ minutes, $24.1 \%$ take care of children every week, and $11.7 \% 20-150$ minutes. It was determined that they do babysitting between 150 minutes, 52.4\% watched TV every week, $43.9 \%$ watched TV between $20-150$ minutes, and $65.6 \%$ used stairs 40 steps or less every day (Table 6).

Table7. The Relation between Women's Physical Activity Levels and BMI Levels

\begin{tabular}{|c|c|c|c|c|c|c|c|c|c|}
\hline Variables & 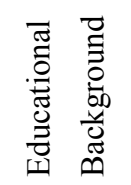 & 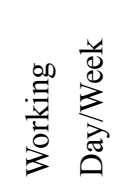 & 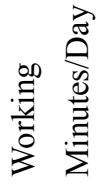 & 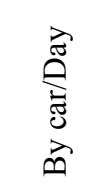 & 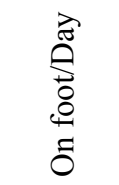 & 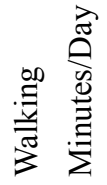 & 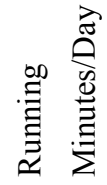 & 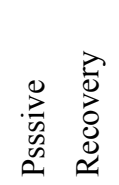 & BMI \\
\hline \multirow{2}{*}{ Educational Background } & $r: 1$ & $-0.21 *$ & 0.03 & $0.25 *$ & $0.32 * *$ & 0.11 & 0.32 & -0.12 & $-0.43 * *$ \\
\hline & $\mathrm{n}: 326$ & 121 & 112 & 84 & 207 & 138 & 28 & 112 & 318 \\
\hline \multirow{2}{*}{ Working Day/Week } & $\mathrm{r}:-0.21 *$ & 1 & $0.21 *$ & 0.16 & $0.30 * *$ & -0.22 & -0.64 & $-0.33^{* *}$ & $-0.23 * *$ \\
\hline & $\mathrm{n}: 121$ & 133 & 124 & 48 & 83 & 54 & 9 & 116 & 126 \\
\hline \multirow{2}{*}{ Working Minutes/Day } & $\mathrm{r}: 0.03$ & $0.21 *$ & 1 & 0.08 & -0.09 & -0.17 & -0.01 & -0.11 & -0.08 \\
\hline & $\mathrm{n}: 112$ & 124 & 124 & 47 & 81 & 50 & 9 & 115 & 117 \\
\hline \multirow{2}{*}{ By car/Day } & $\mathrm{r}: 0.25^{*}$ & 0.16 & 0.08 & 1 & $0.47 * *$ & 0.19 & $0.86^{* *}$ & 0.09 & -0.02 \\
\hline & $\mathrm{n}: 84$ & 48 & 47 & 86 & 46 & 34 & 11 & 44 & 83 \\
\hline \multirow{2}{*}{ On foot /Day } & $\mathrm{r}: 0.32 * *$ & $0.30 * *$ & -0.09 & $0.47 * *$ & 1 & -0.02 & 0.19 & -0.03 & $-0.18 * *$ \\
\hline & $\mathrm{n}: 207$ & 83 & 81 & 46 & 218 & 102 & 17 & 82 & 212 \\
\hline \multirow{2}{*}{ Walking Minutes/Day } & $\mathrm{r}: 0.11$ & -0.22 & -0.17 & 0.19 & -0.02 & 1 & 0.21 & -0.14 & -0.14 \\
\hline & $\mathrm{n}: 138$ & 54 & 50 & 34 & 102 & 148 & 21 & 51 & 147 \\
\hline \multirow{2}{*}{ Running Minutes/Day } & $\mathrm{r}: 0.32$ & -0.64 & -0.01 & $0.86^{* *}$ & 0.19 & 0.21 & 1 & $0.67 *$ & 0.05 \\
\hline & $\mathrm{n}: 28$ & 9 & 9 & 11 & 17 & 21 & 28 & 10 & 28 \\
\hline \multirow{2}{*}{ Passive Recovery } & $\mathrm{r}:-0.12$ & $-0.33 * *$ & -0.11 & 0.09 & -0.03 & -0.14 & $0.67 *$ & 1 & $0.24 * *$ \\
\hline & $\mathrm{n}: 112$ & 116 & 115 & 44 & 82 & 51 & 10 & 124 & 117 \\
\hline \multirow{2}{*}{ BMI } & $\mathrm{r}: 0.43^{* *}$ & $-0.23 * *$ & -0.08 & -0.02 & $-0.18 * *$ & -0.14 & 0.05 & $0.24 * *$ & 1 \\
\hline & $\mathrm{n}: 318$ & 126 & 117 & 83 & 212 & 147 & 28 & 117 & 331 \\
\hline
\end{tabular}

Note. ${ }^{*}: \mathrm{p}<0.05 ; * *: \mathrm{p}<0.01$ 
As seen in Table 7, as the education level of housewives increases, both their car use and walking activities increase $(\mathrm{p}<0.05, \mathrm{p}<0.01)$. Further, BMI levels decrease significantly ( $\mathrm{p}$ $<0.01)$ as education level, working days and walking activities increase. However, both walking activities and running times increase significantly $(\mathrm{P}<0.01)$ as car transportation increases. In addition, as passive rest periods increase, BMI levels also increase $(p<0.01)$.

\section{Discussion and Result}

This study was to delve into the physical activities of housewives in the center of Amasya Province. There is evidence in the literature that people of all age groups, including men and women, who exercise or have a high level of daily activity are more fit and healthy than those who lead a sedentary life. When physically active people are compared with those who are less active, it has been reported that exercise has a protective effect from diseases according to the level of physical activity (Hossack \& Bruce, 1982; Onat et al., 2017).

In their studies, Haşıl Korkmaz and Deniz (2013) examined the relationships between the physical activity levels of adults and their socio-economic levels. It was determined that there is no significant relationship between education level and physical activity level $(r=-0.032 ; p$ $=0.470$ ), although the socio-economic status affects the physical activity level, inactive ones are more common. In addition, it was stated that individuals with high physical activity levels lead a better quality and healthy life. Although there are relationships between socio-economic characteristics and physical activity levels of individuals, it was emphasized that individuals' physical activity levels should be increased. Akdur et al. (2003) compared the physical activity levels of housewives compared to working women, and it was seen that the physical activity levels of housewives were low in daily life and it was revealed that housewives should be made aware of for a more active life and they should do more intense sports. In this present study, the physical activities of housewives are insufficient and most of the physical activities they do are housework (Table 6). In this context, the findigs of this present study corroborated with those of Akdur et al. (2003), and Haşıl Korkmaz and Deniz (2013). Therefore, it is inevitable to increase the duration and quality of daily physical activities of housewives.

In another study, it has been revealed that people who exercise in all age groups or have a high level of daily activity are healthier than those who lead a sedentary life. When physically active people are compared with those who are less active, it is stated that exercise has a protective effect from diseases according to the level of physical activity (Onat et al., 2017). It is also reported that the degree of physical activity is among the main determinants of the development of hypertension and related disorders in the future (Onat et al., 2017). Similarly, Vural et al. (2010) examined the relationship between physical activity level and quality of life of desk workers, $25.2 \%$ of the individuals were not physically active, $48.9 \%$ had low physical activity levels, and only $25.9 \%$ had a sufficient level of physical activity to maintain their health. they said it could be. However, it has been reported that $26.1 \%$ of individuals with a BMI below $25 \mathrm{~kg} / \mathrm{m}^{2}$ are not physically active enough, and the participation rate of individuals with a BMI of $25 \mathrm{~kg} / \mathrm{m}^{2}$ and above is $23.5 \%$. In addition, it was stated that $21.3 \%$ of individuals with a BMI below $25 \mathrm{~kg} / \mathrm{m}^{2}$ and $35.3 \%$ of individuals with a BMI of $25 \mathrm{~kg} / \mathrm{m}^{2}$ 
and above had adequate physical activity. Similarly, in their studies of Leslie et al. (1999) found that physical activity levels of Australian college students and Rowland and Freedson (1994) related to physical activity, fitness and health in children were found to be lower in those with higher BMI. When the physical activity and BMI level relationships of housewives in this study are examined, it is seen that BMI levels decrease significantly $(\mathrm{p}<$ 0.01 ) with the increase in reaching a destination on foot and weekly working days, and increase in the BMI levels with the increase in passive rest periods (Table 7). When we look at the physical activity details of housewives, it is seen that most of them cover housework (Table 6). When the results of this study are compared with the research data of Onat et al. (2017), it is concluded that the protective effect of exercise from diseases and the development of hypertension and related disorders can be determined by the degree of physical activity; There are similarities with other studies in terms of low BMI levels in individuals with high physical activity levels.

In a study investigating the relationship between the physical activity levels and cognitive status of the elders, it was seen that the gender and education level of the individuals affected the physical activity level; It was concluded that there is a strong direct relationship between cognitive status and physical activity level, and that cognitive functions decrease as physical activity level decreases (N. Lök \& S. Lök, 2016). In another study in which physical activity levels of teachers were investigated, it was reported that $20.4 \%$ of individuals with a BMI below $25 \mathrm{~kg} / \mathrm{m}^{2}$ were not physically active, and $15.2 \%$ of those with a BMI of $25 \mathrm{~kg} / \mathrm{m}^{2}$ and above were inactive. As a result, it was observed that teachers were not physically active enough; it was suggested that teachers' physical activity habits, who are expected to be a model for society and their students in all fields, should also be high in terms of social development (Şanlı \& Güzel, 2009). In a study investigating the relationship between physical activity and brain health in older adults, it was concluded that physical activity is a lifestyle factor associated with brain structure and function in older ages (Benedict et al., 2013). In a study titled total daily physical activity and risk of alzheimer disease and cognitive decline in older adults, it was suggested that higher levels of daily physical activity were associated with a reduced risk of alzheimer disease (Buchman et al., 2012). In a study examining complex mental and physical activity and cognitive performance in elderly women, it was emphasized that participation in new stimulating activities in healthy older women may contribute to cognitive fitness and delay cognitive decline (Klusmann et al., 2010). According to the findings of this research, as the education level of housewives increases, both their car use and pedestrian transportation increase $(\mathrm{p}<0.05, \mathrm{p}<0.01)$, however, BMI levels decrease significantly $(\mathrm{p}<0.01)$ as education level, working days and pedestrian transportation increase, however, both pedestrian reach and running times increase significantly $(\mathrm{P}<0.01)$ as the car accessibility increases (Table 7). When we look at the literature results, the positive effects of physical activity on brain structure and functions in advanced ages (Benedict et al., 2013; N. Lök \& S. Lök, 2016), the literature results suggesting that regular and effective daily physical activity level in adults and participation in new stimulating activities in healthy older women can contribute to cognitive fitness (Buchman et al., 2012; Klusmann et al., 2010; N. Lök \& S. Lök, 2016) suggest the relationship between education level and success and physical activity. When evaluated with these results; This study is similar to the results of the 
literature in terms of low physical activity, increased pedestrian access and running time with increased use of cars, although not in terms of higher levels of education in women driving more cars.

Another study emphasizes the importance of increasing physical activity opportunities for women, based on the changes that participation in physical activity creates in women's lives. Considering the low participation of women in physical activity and sports, the development of special projects to increase participation should be one of the priority areas (Bulgu et al., 2007). In this present study, the fact that housewives are more involved in walking, housework and hobbies as physical activity suggests that they should not face health problems in later ages or they should be guided about regular physical activity. Undoubtedly, raising awareness of housewives about regular physical activity on certain days of the week and encouraging them to exercise within the programs should undoubtedly be evaluated. With the increase in the education level of the housewives in this study, both their car usage and walking activity increased $(\mathrm{p}<0.01, \mathrm{p}<0.05)$, and the BMI levels increased significantly $(\mathrm{p}<0.05)$ with the increase in education levels, working days and walking activity. The decrease in BMI levels and the increase in passive rest periods (Table 7) emphasize the importance of providing physical activity opportunities to women. Therefore, even the fact that housewives work every week and provide their transportation on foot increases the duration and quality of physical activity, and decreases their BMI levels significantly $(\mathrm{p}<0.01)$, as observed in Table 7.

In conclusion, it can be suggested that housewives at different educational level in Amasya have some levels of physical activities to some extent, but these activities are mostly walking, shopping, babysitting and doing households.

\section{References}

ACSM (American College of Sports Medicine). (2009). ACSM's Guidelines for Exercise Testing and Prescription (6th ed., pp. 5-7). USA: Lippincott Williams \&Wilkins.

Akdur, H., Doruk, B., Korkmaz, A., Polat, G., \& Şahin, S. (2003). Ev Kadınları ve Çalışan Kadınların Fiziksel Aktivite Düzeyinin Araştırılması. İU Spor Bilimleri Dergisi, 2003-11, 44-46.

Benedict, C., Brooks, S. J., Kullberg, J., Nordenskjöld, R., Burgos, J., Le Grevès, M., ... Schiöth, H. B. (2013). Association Between Physical Activity and Brain Health in Older Adults. Neurobiol Aging, 34, 83-90. https://doi.org/10.1016/j.neurobiolaging.2012.04.013

Buchman, A. S., Boyle, P. A., Yu, L., Shah, R. C., Wilson, R. S., \& Bennett, D. A. (2012). Total Daily Physical Activity and the Risk of AD and Cognitive Decline in Older Adults. Neurol., 78, 1323-1329. https://doi.org/10.1212/WNL.0b013e3182535d35

Bulgu, N., Koca Arıtan, C., \& Aşçı, F. H. (2007). Gündelik Yaşam, Kadın ve Fiziksel Aktivite. Hacettepe J. of SportSciences, 18(4), 167-181.

Ehrman, J. K., Gordon, P. M., Visich, P. S., \& Keteylan, S. J. (2019). Clinical Exercise Physiology (4th ed.). USA: Human Kinetics Publishers. Retrieved from https://www.amazon. 
com/dp/1492546453/ref=rdr_ext_tmb

Glassberg, H., \& Balady, G. (1999). Exercise and heart disease in women. Cardiol Rev, 7, 301-308. https://doi.org/10.1097/00045415-199909000-00015

Haşıl Korkmaz, N., \& Deniz, M. (2013). Yetişkinlerin Fiziksel Aktivite Düzeyleri İle Sosyo-Ekonomik Düzeyleri Arasındaki İlişkinin İncelenmesi. NWSA-Sports Sciences, 8(3), 46-56. https://doi.org/10.12739/NWSA.2013.8.3.2B0094

Heyward, V. H. (2006). Advanced Fitness Assessment and Exercise Prescription (5th ed., pp. 1-5). USA: Human Kinetics.

Hossack, K. F., \& Bruce, R. A. (1982). Maximal Cardiac Function in Sedantary Normal Men and Women: Comparison of Age Related Changes. Appl. Physiol., 4, 799-804. https://doi.org/10.1152/jappl.1982.53.4.799

Kalyon, T. A. (1995). Spor Hekimliği. Ankara: GATA Basımevi.

Karaca, A., Ergen, E., \& Koruç, Z. (2000). Fiziksel Aktivite Değerlendirme Anketi (FADA) Güvenirlik ve Geçerlik Çalışması. Spor Bilimleri Dergisi, 11.

Klusmann, V., Evers, A., Schwarzer, R., Schlattmann, P., Reischies, F. M., Heuser, I., \& Dimeo, F. C. (2010). Complex Mental and Physical Activity in Older Women and Cognitive Performance: A 6-Month Randomized Controlled Trial. J Gerontol A Biol Sci Med Sci, 65, 680-688. https://doi.org/10.1093/gerona/glq053

Leslie, E., Owen, N., Salmon, J., Bauman, A., Sallis, J. F., \& Lo, S. K. (1999). Insufficiently Active Australian College Students: Perceived Personal, Social and Environmental influences. Preventive Medicine, 28, 20-27. https://doi.org/10.1006/pmed.1998.0375

Lök, N., \& Lök, S. (2016). Yaşlıların Fiziksel Aktivite Düzeyleri İle Bilişsel Durumları Arasındaki İlişki. Yeni Sempozyum Dergisi, 54(2), 21-24.

Onat, A., Can, G., Yüksel, H., Ademoğlu, E., Erginel Ünaltuna, N., Kaya, A., \& Altay, S. (2017). Tıp Dünyasının Kronik Hastalıklara Yaklaşımına Öncülük. In A. Onat (Ed.), TEKHARF 2017 (p. 113). Tasarım ve Basım, Turkey. Retrieved from https://file.tkd.org.tr/ PDFs/TEKHARF-2017.pdf

Özer, D., \& Baltacı, G. (2008). İş Yerinde Fiziksel Aktivite (Sağlık Bakanlığı Yayın No: 730). Ankara: Klasmat Matbaacilik.

Rowland, P. W., \& Freedson, P. (1994). Physical Activity, Fitness and Health in Children: A Close Look. Pediatrics, 93(4), 669-672.

Şanlı, E., \& Güzel, N. A. (2009). Öğretmenlerde Fiziksel Aktivite Düzeyi-Yaş, Cinsiyet ve Beden Kütle İndeksi İlişkisi. Gazi Beden Eğitimi ve Spor Bilimleri Dergisi, 14(3), 23-32.

Vural, Ö., Eler, S., \& Güzel, N. A. (2010). Masa Başı Çalışanlarda Fiziksel Aktivite Düzeyi ve Yaşam Kalitesi İlişkisi. Spormetre Beden Eğitimi ve Spor Bilimleri Dergisi, 8(2), 69-75. https://doi.org/10.1501/Sporm_0000000178 


\section{Copyright Disclaimer}

Copyright for this article is retained by the author(s), with first publication rights granted to the journal.

This is an open-access article distributed under the terms and conditions of the Creative Commons Attribution license (http://creativecommons.org/licenses/by/3.0/). 